\title{
Building Bridges: A Restorative Journey at Green Bay Prison Wisconsin
}

\section{Catherine O'Connell}

\begin{abstract}
This article describes the pillars, values and principles of Restorative Justice and the essential components of restorative circles. A specific, circle based, restorative programme that has been running in Green Bay Prison, Wisconsin for over 14 years is described and evaluated in the context of restorative processes. The programme demonstrates that when certain conditions are met, even in a prison context where access to wider community is severely limited, that restorative processes can be highly effective and have long term consequences. An increased use of circle work and surrogate victim and offender restorative processes is recommended with certain provisos.
\end{abstract}

\section{Keywords}

Green Bay Prison, restorative journey, victims of crime

\section{Introduction}

"Restorative Justice is about the idea that because crime hurts, justice should heal" (Braithwaite 2004: 28). The aims of Restorative Justice are to better meet the needs of the people directly involved when a crime happens than is normally possible in traditional criminal justice systems. In the traditional system the focus is on what law was broken and what the appropriate punishment should be for breaking that law. Legal professionals are the active decision makers and the people who have been harmed and those that have harmed are passive in their roles.

In Restorative Justice Systems the focus is on bringing those directly involved in such crimes to the centre of the process and playing an active role in decision making. Howard Zehr (2002) lists three pillars of Restorative Justice. The first focuses on Harm and Needs; what harm was done, to whom was it done and what needs to be done to repair it. The second pillar focuses on Obligation: Who is responsible for the harm and how might he/she/they repair the harm. The third pillar is that of Engagement where victims and offenders are actively engaged in communication and decision making within the process. Restorative Justice covers a range of processes that can be used depending on the context and the need of potential participants. Some of these are Restorative Conferences, Victim - Offender Dialogue and Restorative or Peacemaking Circles (Umbreit \& 
Armour, 2010). What unites all the processes are the values and principles which necessarily underlie them. These values include respect and support for each person, recognition of our interconnectedness, being orientated towards the needs of all participants, an orientation towards nonviolence and the possibility of true transformation (Sawatsky, 2002). Principles of inclusivity and voluntariness are integral to any restorative process (Umbreit \& Armour, 2010).

Our interconnectedness means that any crime that occurs will have ripples across many relationships and contexts (Zehr, 2002). Rather than a crime being seen as something that occurred by an offender to a victim, it needs to be acknowledged that there may be multiple 'victims' or people impacted by any one event. The value of transformation in restorative justice asks that any process be orientated towards the possibility of radical change and development among the persons present rather than a "cheap piece that denies true justice" (Sawatsky, 2002). Transformation is a possibility only when certain conditions such as safety, respect and care for each person is met and our interconnectedness and humanity is recognised by all present. When blame and shaming are present, people protect themselves by putting up defence mechanisms and closing down (Morris 2002; Umbreit \& Zehr, 2003). This will deny the possibility of empathy, openness and understanding of another person's viewpoint to take place.

\section{Restorative Circles}

Talking circles were used historically by communities, especially indigenous populations, to manage and respond to conflict, crime or difficulties within the community. Modern restorative circles use the process as a way of responding to harm done to a group or community in a way that fosters connectedness, accountability and healing (Umbreit \& Armour, 2010).

The purpose of any Restorative or Peacemaking Circle is to create a safe, respectful environment where people can meet and share meaningfully their authentic reactions to an event or situation. This involves hearing others speak in a deep way and also be heard deeply by others in the circle. This is achieved by having a prepared and structured approach and by the use of a 'talking piece' that is passed around from person to person. In restorative circles, the person with the talking piece is asked to speak from the heart in answer to a question posed by the facilitator(s). The role of the others in the circle is to listen deeply to what the speaker is saying. No one may interrupt the speaker except (rarely) the facilitator or 'circle keeper'. The role of the circle keeper is to open, close and manage the process in such a way that it is a safe respectful non-judgmental space for people to engage in dialogue.

\section{Restorative Circles in Green Bay Prison: Day One}

In April 2013, the author took part in a Restorative Justice Programme in Green Bay Maximum Security Prison, Green Bay, Wisconsin, United States. 
On day one of the Restorative Circle more than thirty people queue up in the small entrance to Green Bay Prison and go through security before being admitted into the prison itself. The circle is facilitated by 'Judge' Janine Geske, director of Marquette University Law School Restorative Justice initiative, an ex-Supreme Court judge for Wisconsin state. Professor Geske initiated this workshop 14 years ago and runs it twice yearly.

The community group are briefed by both prison staff and Professor Geske around etiquette and safety and asked to commit to the boundaries necessary to keep the process safe and ensure its continuation. The participants are not allowed exchange phone numbers, addresses or engage in physical contact with prisoners. The participants are asked to speak in the circle as 'themselves' and not in any role such as helper, teacher or supporter of prisoners. The group are then asked to go into the next room and enter the circle where over 30 prisoners are already seated. Their chaplain is the only prison staff member there. Introductions are made and a quiet hum develops in the room.

The circle begins by the lighting of a candle and the group are welcomed into the circle. The group are acknowledged for taking the time and effort to attend this process. Judge Geske stresses that the outside community cares what happens to people in prison and that is why so many people have taken time off work, paid to travel and arrived here to participate in the circle. The operating principles of restorative justice are explained with examples given. The importance, role and the significance of the talking piece is explained. People are asked to speak from their heart and listen deeply to the other speakers in the circle.

The opening question asks the participants to talk about someone who has touched their lives in a deep way. Whoever comes to mind is the right choice for the speaker. People speak about their children, their mothers, friends, teachers, brothers and sisters, other family members and strangers who touched their lives in meaningful ways. Stories shared open the group up to each other. There are powerful, emotional stories, real and meaningful to the speakers and the listeners alike.

The group breaks for lunch and on this day the community members are served the lunch that the prisoners eat. There is a meat dish, some fruit, some salad and milk. All trays are the same.

The afternoon session begins by Judge Geske instructing the people in the room to break up into smaller groups. Each group works with flip chart paper and markers to answer two sets of questions around restorative justice. The atmosphere is energetic and both the exercises and their presentations result in comradeship, laughter and animation. The circle closes with another question for the circle about the impact that this day has had on them. Everyone speaks and people are less tentative than at the start of the day. Judge Geske outlines what tomorrow will be like and notes that it may be a difficult day for some people. This is the part of the process where community members who have been seriously victimised and impacted by crime will talk in the circle and describe what happened to them. Before participants leave the prison, there is a final circle checking out how everyone is managing in this new environment. 


\section{Day Two: Victims of Crime Tell their Stories}

The second day begins with an early morning briefing. All participants are asked to sit beside someone different today to allow for as much diverse experience as possible. Janine opens the circle and asks the group to honour those who have come here to talk about the crimes committed against them by listening deeply. She asks for those who have committed crimes to wonder if the people they victimised might have experienced some of the impacts of crime that will be described in the room today. One by one the people who have been victims of violent crimes describe their experiences. One person describes being held up at gun point and being raped. Another describes being mugged and hurt in the process. A third person speaks of her 19-year-old child who was killed by a driver under the influence of alcohol.

All the victims describe graphically, moment by moment what had happened to them and their thoughts and feelings as it was happening. They then describe the impact on them and others at the time of the crime and further on in time up until today. Some of the emotions described are pain, hurt, anger, loneliness, devastation, fear, dread, isolation, panic and lack of trust. With a break for lunch, the survivors' accounts took most of the day. The day closes with a circle where the participants are asked to respond to what had been heard today. The atmosphere is sombre and participants speak of being impacted deeply and honoured to have been witness to deeply honest, vulnerable and painful life stories. Finally, Janine asks the men who are incarcerated to respond in some way when they are in their cells that night to show their appreciation to the speakers for being willing to share such a deep and traumatic part of their lives. After the large circle closes there is a final smaller circle for those who will be leaving the prison and they are asked how they are.

\section{Day Three: Responding to the stories}

On the third morning all the non-incarcerated participants gather in the prison for a briefing before entering the circle room. On entering the circle, people sit down and conversation begins immediately. Everyone knows one another by now and it appears completely natural that over sixty people are gathered in this room for a process such as this.

The morning circle asks all present to respond to what was heard from the three survivors the day before. People's responses vary hugely but all acknowledge the harm done and respond to the survivors in some way and thank the survivors. The prisoners, or "men in green" as they are referred to, reply in varying ways, some wonderfully creative including cards, songs, poems, commitments for the future and honest open acknowledgment of the pain of the survivors and seeing the impact that they might have inflicted on victims of their crimes. The survivors also respond and report that the experience is worthwhile, meaningful and rewarding for them.

After lunch, Janine breaks the circle up into smaller groups and asks the groups to play a game, again with a restorative theme, which involves some acting ability. With minimal preparation time, each group gets a chance to present their five-minute play to the larger group. Much merriment 
is heard while the rehearsals are going on and the final plays are met with hoots of laughter and much applause. The circle closes with a question that asks everyone to commit to doing something different to mark these three days. One person says that they will not speed while driving in future. A prisoner vouches to use his power and influence for good and to help stop bullying and intimidation that goes on regularly. A man commits to leading a different life to prior when he leaves prison next year. All present respond with varying commitments or remarks. The workshop ends. People say goodbye. Many of the prisoners make a point of saying goodbye to every single person in the room. The wardens are calling time and the prisoners are finding it hard to go out of this room and go back to prison life.

\section{Review}

One of the ways people cope with stressful situations is to shut down emotionally. Those who become imprisoned have to leave their communities, families, friends, relations and cope in a new culture which is a form of community in its own right with its own rules, hierarchy and norms (Keve, 1974). On entering Green Bay Maximum Security Prison, there is a sign over a doorway that says prison rape is not tolerated in the prison. This acknowledges the possibility for violation of prisoners despite the prison mission, values and care taken by staff (Keve 1974). People become hardened, defensive and shut down as an intelligent coping mechanism to their circumstances (JoseKampfner C., 1990; Sapsford. R.,1978). Despite this, the restorative process as described above has real impacts on prisoners, prison life and on the staff working in the prison and the programme is now welcomed by prison staff.

On the first day of the workshop the Warden or Governor, Mr Michael Baedon told the external participants of the workshop that this intervention has significantly reduced the incidents of violence within the prison and reduced the stress of prison life for prisoners and staff working there. Those who attend this course demonstrate significantly reduced incidents of problematic behaviour. The survivors who speak at the workshop describe the impact as rewarding and satisfying.

\section{Why it Works}

Preparation is the key ingredient to any successful restorative process (Umbreit \& Armour, 2010; Greenwood, 2005). The Restorative Justice workshop has impact and is successful because of the preparatory work that has gone on beforehand. The workshop is part of a four month programme entitled "Challenges and Possibilities" that all prisoners must attend. They work on their personal development, self-awareness and self-esteem, developing responsibility and accountability, managing anger and learning to be successful both in and out of prison. They also learn about restorative justice. A number of external facilitators work with the men. The participants (in prison) have to apply in writing for the course saying why they wish to do it and they need to complete a number of tasks before being accepted onto it. So before the three-day restorative circle process a lot 
of work has gone on to allow participants be comfortable opening up, discussing feelings and listening to others, demonstrating excellent preparation work that will enhance outcomes.

A second reason that this process works well is because it maps onto and shares the values of best practice restorative circle processes. The survivors and the offenders of crime are central to this process. The principles of voluntariness, inclusivity, broad participation and values such as interconnectedness, respect, safety, being non-judgmental and care are evident in the above descriptions. Thirdly, this process is structured around the pillars of restorative justice; engagement and building community, addressing the harm and repairing the harm and is integral to the significant outcomes of this project. This is highlighted in more detail below.

\section{Building Community}

Community is described as "a group of people living in the same place or having a particular characteristic in common" or "the condition of sharing or having certain attitudes and interests in common" (Oxford English Dictionary, n.d.). The processes on day one of the restorative circle are specifically designed to build community and bridge the gaps between those living within and outside of prisons. The opening question in such a process should be something that allows everyone to see the humanity and the commonality between people. In speaking about vulnerability and the people who touched them, the participants demonstrate that the ability and need to love, be loved and belong is universal (Glasser, 1998) irrespective of race, gender, class, education or wealth. The bringing of people together from a variety of backgrounds and situations using the processes described to emphasise shared values, understandings and the similarities between them rather than differences is building community. This, in turn, reduces the social distance necessary for moral indifference (Cayley,1998) on the part of both the external and the incarcerated participants. It opens up the possibility for people to accept responsibility for crimes committed. The broad mix within the circle also meets the principle of broad participation as outlined in Pranis et al, 2003. Judge Geske has commented that this would be further enhanced by an increase of black external participants. The vast majority are white.

\section{Who is Harmed and What is the Harm?}

Hearing who is harmed and the ways in which harm is manifested is essential to any restorative process. This is thoroughly addressed on day two of the Green Bay workshop when the stories of victims are told and heard. The power of this part of the process works for both the victims of crime who speak and also for those whose role is to listen. The speakers have worked with the facilitator(s) prior to the workshop in preparation for the restorative circle. They are listened to deeply and are honoured and validated by the responses of others that day and especially the following day. The listeners hear the ongoing impact of a crime on someone that is part of the 'community' built up in the room. This process can be seen as a type of surrogate victim offender 
process where a group is made up of surrogate victims and offenders and community members gathered to support everyone.

\section{Repairing the Harm}

The third phase of any restorative process is about repairing the harm. This does not mean that damage done goes away or that one can ever be the same as before the crime but that an attempt is made to repair the harm in some way. Again, the Green Bay workshop addresses repairing the harm done to the victims of crime by acknowledging and honouring them in a number of ways. Firstly, a safe space is created where the stories told by victims of crime are central to the process. Secondly the victims are listened to deeply. Thirdly people respond verbally to the stories they have heard, giving their internal response rather than their thoughts or comments. Fourthly, on the final day of the workshop various action based responses are 'given' to the victim by the prisoners in the form of poems, cards, letters, commitments. Finally, all sixty plus members of the community share one action that they are committing to as a result of hearing the victims' stories.

\section{Conclusion}

An overview of Restorative Justice and Restorative Circles is given along with an account of a three-day restorative workshop in Green Bay Prison Wisconsin. The programme had built into it the values, pillars and principles of restorative work that are critical to any process intending to 'restore' individuals and communities in some way. This is evident in the workshop and the preparatory work done with both prisoners and survivors of crime. Central to the process are the voices and engagement of survivors, offenders and community members. While there has not been huge research into circle processes, high participant satisfaction is a significant finding across many studies (Umbreit \& Armour, 2010). This was voiced by all participants in the programme and is evident in the behavioural statistics from the Prison Warden.

The article recommends further use of restorative circles in a flexible way to build understanding across people and communities. This must incorporate extensive preparation, trained facilitators and the adoption of values and principles intrinsic to good circle keeping as outlined above. Further use of 'surrogate' victim and offender restorative work is recommended by Umbreit and Armour (2010: 25). This can give voices to people who to date have not had the opportunity to speak and be heard. 


\section{References}

Braithwaite, J. (2004) "Restorative Justice and De-Professionalization" in The Good Society, 13 (1): 2831 Penn State University Press.

Cayley, D. (1998). The Expanding Prison: The crisis in crime and punishment and search for alternatives.

Cleveland, OH: Pilgrim Press.

Glasser, W. (1998). Choice Theory: A new psychology of personal freedom. New York: Harper Perennial.

Greenwood, J. (2005). The Circle Process: a path for restorative dialogue. St. Paul, MN: Center for Restorative Justice and Peacemaking, University of Minnesota.

Jose-Kampfner, C. (1990) "Coming to Terms with Existential Death: An Analysis of Women's Adaptation to Life in Prison," Social Justice", 17 (2): 110 -125.

Keve, P. (1974). Prison Life and Human Worth. Minneapolis: University of Minnesota Press.

McCorkle, R. (1992) "Personal Precautions to Violence in Prison", in Criminal Justice and Behavior, 19, $160-173$.

Morris, A. (2002) "Shame, Guilt and Remorse: Experiences from family group conferences in New Zealand", in I. Weijers \& A. Duff (Eds). Punishing Jweniles: Principles and Critique. Oxford: Hart Publishers.

Pranis, K., Stuart, B., \& Wedge, M. (2003). Peacemaking Circles: From Crime to Community. St. Paul, MN: Living Justice Press.

Sapsford, R. (1978) "Life Sentence Prisoners: Psychological Changes During Sentence" in "The British Journal of Criminology"18: 128-145. Oxford University Press.

Sawatsky, J. (2001) "A Shared Just Peace Ethic: Uncovering Restorative Values" in "Conciliation Quarterly", 20 (3): 12-13.

Umbreit, M. S., (2008). Peacemaking Circles. St Paul, MN: Center for Restorative Justice and Peacemaking, University of Minnesota.

Umbreit, M., M. Armour (2010). Restorative Justice Dialogue: An Essential Guide for Research and Practice. New York: Springer Publishing Company.

Umbreit, M. \& Zehr, H. (2003). "Restorative Family Group Conferences: Differing models and guidelines for practice". in E. McLaughlin, Fergusson, G. Hughes \& L. Westmorland (Eds), Restorative justice: Critical issues. Thousand Oaks, C.A: Sage.

Zehr, H. (2002) The Little Book of Restorative Justice. Intercourse, P.A: Good Books. 
Catherine O'Connell is a long-time member of Facing Forward, an accredited Mediator with the Mediators Institute of Ireland and a conflict management coach, coach mentor and trainer in CINERGYTM Conflict Management Coaching. With a background in both Business and Community work, an M.A in Mediation and Conflict Resolution and B.Sc. in Psychology, Catherine develops training in Conflict Management, Personal Development and Communications skills for leaders, groups and organisations. She has a huge interest in developing Restorative Practices in our society, communities, families and organisations.

Catherine is the founder of Blossom Development. She is a trainer, mediator, conflict management coach and mentor for Mediation Northside, a community organisation in North Dublin City. She is a member of the international Association of Conflict Resolution, the European Council for Restorative Justice and the U.K. Restorative Justice Council. Catherine is a member of the M.I.I conference committee member since 2009. 